\title{
Effects of steroid hormones on differentiated glandular epithelial and stromal cells in a three dimensional cell culture model of the canine endometrium
}

Cordula Bartel $^{1^{*}}$, Alexander Tichy ${ }^{2}$, Susanne Schoenkypl ${ }^{3}$, Christine Aurich ${ }^{4}$ and Ingrid Walter ${ }^{1,5}$

\begin{abstract}
Background: Oestrogens and progesterone have a significant impact on the endometrium during the canine oestrous cycle. Their receptors mediate plasma steroid hormone levels and are expressed in several endometrial cell types. Altered steroid receptor expression patterns are involved in serious uterine diseases; however the mechanisms of hormone action during pathogenesis in these tissues remain unclear. The development of 3D culture systems of canine endometrial cells provides an opportunity for the effects of steroid hormones to be quantitatively assessed in a more in vivo-like setting. The present study aimed to determine the effects of the steroid hormones $17 \beta$-estradiol $(E)$ and progesterone $(P)$ on the expression of the oestrogen and progesterone receptors (ER and PR), and on proliferative activity, in a 3D co-culture system of canine uterine origin, comprising differentiated endometrial glands, and stromal cells (SCs).
\end{abstract}

Results: Morphology, differentiation, and apical-basolateral polarity of cultured glandular epithelial cells (GECs) were comparable to those in native uterine tissue as assessed by immunohistochemistry using differentiation markers ( $\beta$-catenin, laminin), lectin histochemistry, and transmission electron microscopy. Supplementation of our 3D-culture system with $E$ (at 15, 30 and $100 \mathrm{pg} / \mathrm{mL}$ ) resulted in constant levels of ER expression in GECs, but reduced expression levels in SCs. PR expression was reduced in both GECs and SCs following treatment with E. $3 \mathrm{ng} / \mathrm{mL}$ P resulted in increased ER expression in GECs, but a decrease in SCs. PR expression in GECs increased in all P-treated groups, whereas PRs in SCs decreased with the lowest and highest doses, but increased with the middle dose of treatment. Proliferative activity, assessed by Ki67 staining, remained below 1\% in all assays and cell types.

Conclusions: The present study demonstrates the applicability of our 3D organotypic canine endometrium-derived culture system for cellular-level studies. 3D cultures represent near-physiological systems allowing reproducible quantitative experimentation, thus reducing the need to experiment on living animals. The results of the present investigation emphasize the importance of co-culture of the uterine glands with SCs, as it was shown that the responsiveness of the different cell types to steroid hormones were divergent in the 3D cell culture model.

Keywords: Dog, Endometrium, 3D cell culture, Glandular epithelium, Stroma, Steroid hormones, Oestrogen receptor, Progesterone receptor, Proliferative activity, Immunohistochemistry, Apical polarity

\footnotetext{
* Correspondence: cordula.bartel@vetmeduni.ac.at

'Department of Pathobiology, Institute of Anatomy, Histology and

Embryology, University of Veterinary Medicine, Veterinaerplatz 1,

Vienna A - 1210, Austria

Full list of author information is available at the end of the article
} 


\section{Background}

Altered patterns of oestrogen receptor (ER) and progesterone receptor (PR) expression have been suggested to play roles in the etiology of serious, occasionally lifethreatening pathological alterations of the canine endometrium, concerning mainly the uterine surface, glands and the stroma, including cystic endometrial hyperplasia $(\mathrm{CEH})$, and pyometra [1]. Alterations in the plasma levels of progesterone are involved [2,3], but detailed knowledge of processes controlling these serious endometrial alterations at the cellular and molecular levels is lacking. As a prerequisite tool to study the effects of steroid hormones and other processes on the cellular level, a three dimensional (3D) co-culture system of the canine endometrium was established in our laboratory [4], and further developed for the present study. Previous in vitro studies demonstrated the responsiveness of canine endometrial epithelial and stromal cells to oestrogen and progesterone in a monolayer cell culture system [5]. However a 3D co-culture system can much better mimic conditions present in the endometrium, due to the maintenance of epithelial cell differentiation, cell migration, cell signaling and drug responses [6-10]. The 3D co-culture system is designed to provide an appropriate microenvironment for the correct structure and function of epithelial cells, including cell-cell interactions, media, and composition of extracellular matrix (ECM), which defines cellular and tissue stiffness [10]. The structure and function of cells are closely intertwined, and therefore we used primary isolated uterine glands with their natural tissue structure featuring polarized glandular epithelial cells (GECs), surrounded by their original basement membrane, and stromal cells (SCs). The different cell types, in particular endometrial GECs, surface epithelial cells, and SCs, show strong interactions with diverse expression patterns of ERs and PRs during the canine oestrous cycle and among the different regions of the canine endometrium $[11,12]$. It is well known that the different cell types of the canine endometrium show different ER and PR expression patterns during the oestrous cycle in relation to fluctuations of plasma steroid concentrations [11-13]. Increased plasma oestrogen concentrations in general lead to an increased expression of ERs and PRs, whereas a rise in plasma progesterone levels is accompanied by decreased expression of ERs and PRs [11,12]. Increasing plasma oestrogen levels have been reported to lead to an increased ER expression in endometrial luminal epithelial and myometrial cells, but to a decreased ER expression in SCs and GECs $[5,11,12]$. It has been shown that proliferation patterns of the canine endometrium are influenced by plasma steroid hormone levels as well $[14,15]$. Oestrogens stimulate growth, vascularity and edema of the endometrium as well as proliferation of the glandular epithelia, whereas progesterone promotes proliferation of SCs and secretory activity of the endometrial glands $[3,11,12,16]$. These results underline the distinct responsiveness of the different endometrial cell populations to the respective steroid hormones. The advantages of 3D co-culture were studied in human systems with a main focus on mammary glandular epithelial cells to mimic and study the human breast in culture [17-20], as well as endometrial and ovarian cells $[21,22]$, mainly for cancer research. In veterinary medicine only a few 3D cell cultures have been established for experimental approaches [23-26], and a cell culture system of complete endometrial glands with their specific environment has not existed until now.

The aim of our study was to apply our established 3D co-culture system, which mimics the in vivo canine endometrium with intact primary uterine glands in their original structural environment (basement membrane, ECM, SCs), to study the influence of steroid hormones on the uterine glands and the surrounding SCs. We hypothesized that different physiological concentrations of progesterone or oestrogens influence the expression patterns of steroid hormone receptors in these cells in vitro. Furthermore, the effects of these hormones on proliferative activity of the in vitro endometrial model were evaluated. Besides a morphological evaluation (histology and transmission electron microscopy) several markers (immunohistochemistry for $\beta$-catenin, laminin, cytokeratin, vimentin, Ki67, ER, PR) were used to verify differentiation as demonstrated by cell-cell-contacts, cytoskeleton, polarity of the cultured glandular epithelial cells, and lectin binding patterns, also in comparison with the in vivo situation in the canine endometrium. This 3D cell culture system allows the study of physiological and pathological mechanisms acting in the canine endometrium at the cellular level, which is almost impossible in the living animal. On the basis of the demonstrated responsiveness of the 3D cultured endometrial GECs and SCs to supplemented steroid hormones we expect this system to make a significant contribution to the knowledge about the endocrine regulation of endometrial cell populations. In addition, the development of similar 3D cultures will be applicable for the experimental investigation of other biological systems.

\section{Methods}

\section{Animals and tissue sampling}

Uterine tissue for the present study was collected from routine ovariohysterectomy of ten bitches of different breeds (Deer Pinscher, Beagle, Collie, Chihuahua, Yorkshire Terrier, Pekinese, Great Dane and two mongrel) and ages (mean age: two years, range: 1-5 years). Surgery was performed under general anesthesia at the Department of Companion Animals and Horses, Section of Obstetrics, Gynecology and Andrology of the University of Veterinary Medicine at Vienna, Austria and at a veterinary practice in Vienna, Austria. 
Tissue sampling and evaluation as well as anonymized publication of the received data were in accordance with the pet owners and the project was approved by the local ethical commission at the Vetmeduni Vienna (ETK) to be based on the respective regulations of good scientific practice.

The dissected uterine tracts were transported in sterile Dulbecco's Phosphate Buffered Saline (DPBS-AB, without Ca \& Mg; PAA Laboratories, Pasching, Austria) containing $0.5 \%$ Gentamicin (PAA Laboratories) and 1.5\% Nystatin suspension (10,000 units/mL in DPBS; Sigma Aldrich, Vienna, Austria), at $4-8^{\circ} \mathrm{C}$.

\section{Native tissue histology}

Visceral fat was removed from the uterine tracts under sterile conditions. For the comparison between in vivo endometrial tissue and cultured uterine glands, samples $\left(1 \mathrm{~cm}^{3}\right)$ of the uterine horns (cranial and caudal regions) as well as of the uterine body (bifurcation) were separated and immersion fixed in $4 \%$ buffered formaldehyde for 24 to $48 \mathrm{hr}$ at $4^{\circ} \mathrm{C}$ and then embedded in Paraplast $^{\circ}$ (Vogel, Giessen, Germany). Samples from the same regions were reduced to $1-2 \mathrm{~mm}^{3}$ and separated for transmission electron microscopy.

For the determination of the oestrous cycle stage, histological sections of $2 \mu \mathrm{m}$ thickness were cut and stained with haematoxylin and eosin (H\&E) according to Romeis [27]. Histological evaluation of the stage of the oestrous cycle was performed according to Barrau et al. [16] and Galabova et al. [14]. Furthermore, immunohistochemical oestrogen and progesterone receptor expression patterns of the endometrial tissue were evaluated for cycle stage determination according to Vermeirsch et al. [12,28], and allocation of proliferative activity was assessed by antiKi67 staining, according to van Cruchten et al. [15].

\section{$3 \mathrm{D}$ cell culture}

Isolation of uterine glands and stromal cells

Uterine tissue preparation for 3D cell culture was performed according to Stadler et al. [4] with modifications. In brief, the uterine tissue was rinsed with DPBS-AB and cut into pieces of about $2 \mathrm{~cm}^{2}$ with sterile scalpel blades. These pieces were opened longitudinally and then cut into further pieces $\left(2-3 \mathrm{~mm}^{2}\right)$. Subsequently, the minced tissue was placed into a Petri dish $(80 \mathrm{~cm}$ diameter) and gently rinsed three times with DPBS-AB to remove the majority of erythrocytes. Subsequently, pieces were placed into a glass beaker containing standard medium [88\% medium M199 with L-glutamine, $10 \%$ fetal calf serum FCS, $1 \%$ antibiotic-antimycotic solution (PAA Laboratories, Pasching, Austria) and 1\% Fungizone ${ }^{\circ}$, liquid (GIBCO / Life Technologies, Austria)] with $1 \mathrm{mg}$ collagenase I / $\mathrm{mL}$ (from Clostridium histolyticum, prepared from Type XI, Sigma-Aldrich, Vienna,
Austria) and a sterile magnetic stirrer for tissue disintegration. The mixture was mildly stirred for 4-6 hr (depending on the tissue structure of the obtained uterus) in a tissue culture incubator at $37^{\circ} \mathrm{C}$ and $5 \% \mathrm{CO}_{2}$. Subsequently, the solution was filtered through a stainless steel filter (pore size $280 \mu \mathrm{m}$; Bellco Glass, Dunn Labortechnik, Asbach, Germany) to remove tissue parts that had not disintegrated. The filtered solution containing uterine glands and stromal cells was further filtered through a cell filter (pore size $40 \mu \mathrm{m}, \mathrm{BD}$ Falcon ${ }^{\mathrm{Tm}}$, Becton Dickinson GmbH, Heidelberg, Germany) into a sterile Petri dish. Isolated stromal cells passed through the filter whereas glandular structures remained on the filter mesh and were washed into a separate Petri dish with standard medium. Stromal and glandular fractions were centrifuged in a sterile $15 \mathrm{~mL}$ tube for one minute at $0.6 \times$ g. Each pellet was resuspended in $1 \mathrm{~mL}$ sterile distilled water for $30 \mathrm{~s}$ to eliminate remaining erythrocytes. Afterwards, pellets were washed in $10 \mathrm{~mL}$ standard medium and the fractions were centrifuged again. The supernatant was removed and the pellets were resuspended in hormone-free medium (stromal fraction with $1300 \mu \mathrm{l}$, glandular fractions with $5200 \mu \mathrm{l}$ ).

The hormone-free medium was prepared by filtration of standard medium through a Sep-Pak C18 column (Sep-Pak C18 Classic Type, Waters, Vienna, Austria) prepared as specified by the manufacturer, to extract present steroids from the standard cell culture medium containing fetal calf serum, to enable the application of specified hormone concentrations in the cell culture system. The concentrations of $\mathrm{E}$ and $\mathrm{P}$ in the standard medium (M199 + 10\%FCS) were among $11 \mathrm{pg} / \mathrm{mL} \mathrm{E}$ and $25 \mathrm{pg} / \mathrm{mL} \mathrm{P}$, determined with a competitive enzyme immunoassays using biotin linked steroids [29]. After filtration through the Sep-Pak C18 column neither estrogens nor 20-oxo-gestagens (including progesterone) were present in the hormone free medium.

At this preparation stage, glandular $(200 \mu \mathrm{l})$ and stromal $(50 \mu \mathrm{l})$ fractions were collected for histological and electron microscopical evaluation of the morphological state of the cells after the isolation procedure.

\section{Experimental design}

Experiments were performed on Matrigel ${ }^{\text {Tx }}$ 24-well plates (BD BioCoat 24-well Multiwell Plates, Becton Dickinson $\mathrm{GmbH}$, Heidelberg, Germany), thawed from $-20^{\circ} \mathrm{C}$ to $4^{\circ}$ $\mathrm{C}$ for 5-7 hr. After the thawing process, six wells were rehydrated with $1 \mathrm{~mL}$ standard medium, 18 wells with 1 $\mathrm{mL}$ hormone free medium for $30 \mathrm{~min}$ at $37^{\circ} \mathrm{C}$. Media were removed and $750 \mu \mathrm{l}$ fresh medium (6x standard medium, 18 $\times$ hormone-free medium) were added to each well, and plates were ready to use. Plates were provided with $200 \mu \mathrm{l}$ glandular fraction and $50 \mu \mathrm{l}$ stromal fractions in each well. 
Three different physiological concentrations of the steroid hormones $17 \beta$-estradiol (Sigma Aldrich, Germany; $\mathrm{E} ; 15,30$, and $100 \mathrm{pg} / \mathrm{mL}$, i.e. $5.5 \times 10^{-2}, 11 \times 10^{-2}$, and $36.7 \times 10^{-2} \mathrm{nM}$, respectively) and progesterone (Sigma Aldrich, Germany; P; 3, 15, and $30 \mathrm{ng} / \mathrm{mL}$, i.e. 9.54, 47.7, and $95.4 \mathrm{nM}$ respectively) were tested. On each 24-well plate, 6 wells prepared with hormone-free medium were supplemented with the respective hormone solution $(10 \mu \mathrm{L} / \mathrm{mL}$ medium) of one concentration. Six wells with standard medium and 6 wells with hormone-free medium served as controls. 3D co-cultures with uterine glands and stromal cells were incubated for either $24 \mathrm{hr}$ or $48 \mathrm{hr}$ in each medium group. Medium was changed after $24 \mathrm{hr}$, including two washing steps with pre-warmed DPBS. Each hormone concentration was tested in three independent experiments (tissue originating from three different dogs).

Additional experiments (12 wells) with standard medium containing $10 \mu \mathrm{l}$ sterile distilled water / $\mathrm{mL}$ represented the control for the solvent of the steroid hormones.

\section{Preparation of $3 D$ co-culture samples}

To harvest the cultured uterine glands and stromal cells, the Matrigel ${ }^{\mathrm{IM}}$ gel was gently mixed with the medium in the well and then aspirated using a plastic pipette (tip diameter 2-3 $\mathrm{mm}$ ) to ensure the integrity of the glandular structures. The gel containing the glandular structures and stromal cells was transferred to a $2 \mathrm{ml}$ tube, centrifuged $(3 \mathrm{~min}, 0.84 \times \mathrm{g}$ ) and the gelatinous pellet was treated with the respective fixative. At each time point, one well was used for electron microscopy and two wells were pooled for histological preparation.

\section{Histology}

For histological preparation samples were fixed for $24 \mathrm{hr}$ at $4^{\circ} \mathrm{C}$, then centrifuged again $(3 \mathrm{~min}, 0.84 \times \mathrm{g}$ ) and pellets were embedded in Histogel $^{\bullet}$ (Richard-Allan Scientific, Microm International, Walldorf, Germany; as specified by the manufacturer) and subsequently in Paraplast $^{\circ}$ (Vogel) by means of an automatic embedding device. Serial sections of $3 \mu \mathrm{m}$ thickness were cut and stained with H\&E according to Romeis [27].

\section{Immunohistochemistry}

Serial sections $(3 \mu \mathrm{m})$ of native tissue and $3 \mathrm{D}$ cultures were mounted on APES/glutaraldehyde -coated slides. Endogenous peroxidase activity was blocked by incubation in $0.6 \% \mathrm{H}_{2} \mathrm{O}_{2}$ in methanol for $15 \mathrm{~min}$ at room temperature. A protein block (1.5\% normal goat serum) was used to minimize unspecific binding of the primary antibody. The unlabeled primary antibodies (antioestrogen receptor, anti-progesterone receptor, anti-Ki-67; for sources, pre-treatments and dilutions see Table 1) were detected with the ImmunoVision secondary system (ImmunoVision Technologies, Brisbane, CA, USA) using DAB (3,3'diaminobenzidine-tetrahydrochloride substrate in Tris buffer $\mathrm{pH} 7.4$ and $0.03 \% \mathrm{H}_{2} \mathrm{O}_{2}$ ) as chromogen. Finally, slides were washed with distilled water, counterstained with haemalum, dehydrated and mounted by use of xylene-soluble medium (DPX, Fluka, Buchs, Switzerland). For the fluorescent detection (anticytokeratin, anti-vimentin, anti-laminin, anti- $\beta$-catenin) Alexa Fluor ${ }^{\mathrm{Tm}} 488$ goat anti-mouse (Molecular Probes, Eugene, OR, USA; dilution 1:100) secondary antibody was used and nuclear counterstaining was performed with 4,6-diamidino-2-phenylindole (DAPI, Molecular Probes / Life Technologies, Vienna, Austria).

Negative controls were performed by substitution of the primary antibodies with PBS. Evaluation of the sections was performed using light microscopy (Polyvar, Reichert-Jung, Vienna, Austria) and confocal laser scanning microscopy (Zeiss, LSM 510 Meta, Vienna, Austria).

\section{Lectin histochemistry}

Paraffin sections were pre-treated as described by Bartel et al. [30] and incubated with the respective biotinylated lectin (Ulex Europaeus Agglutinin - UEA I, Wheat Germ Agglutinin -WGA; Helix Pomatia Agglutinin - HPA, Vector Laboratories, Burlingame, CA, USA) at a concentration of $10 \mu \mathrm{g} / \mathrm{mL}$. After incubation, sections were washed in PBS solution and incubated with avidin-biotin

Table 1 Sources, pre-treatments and dilutions of the antibodies used in this study

\begin{tabular}{|c|c|c|c|c|}
\hline Antibody & Source & Clone & Pre-treatment & Dilution \\
\hline Anti-oestrogen receptor & Zymed / Life Technologies, USA & Poly rabbit & $\begin{array}{l}\text { Nuclear Decloaker. Biocare Medical. Concord. } \\
\text { CA. USA. pH 9.5. 3× } 5 \text { min. }\end{array}$ & $1: 200$ \\
\hline Anti-progesterone receptor & Immunotech SAS, Marseille, France & 10 A9 rabbit & Boil in citrate buffer, pH 6.0, $4 \times 5$ min. & $1: 200$ \\
\hline Anti-Ki-67 & Thermo Fisher Scientific, Fremont, CA, USA & SP6 rabbit & Boil in citrate buffer, $\mathrm{pH} 6.0,3 \times 5$ min. & $1: 400$ \\
\hline Anti-cytokeratin & Sigma-Aldrich, Germany & 8.13 mouse & Boil in citrate buffer, $\mathrm{pH} 6.0,2 \times 5$ min. & $1: 100$ \\
\hline Anti-vimentin & Dako, Glostrup, Denmark & V9 mouse & No pre-treatment & $1: 400$ \\
\hline Anti-laminin & Dako, Glostrup, Denmark & Poly rabbit & $\begin{array}{l}\text { Protease (Sigma) 1mg/mL PBS, } 20 \text { min, } \\
\text { room temp. }\end{array}$ & $1: 500$ \\
\hline Anti- $\beta$-catenin & Acris Antibodies, Herford, Germany & 9G2 mouse & Boil in citrate buffer, pH 6.0, $3 \times 5$ min. & $1: 100$ \\
\hline
\end{tabular}


-peroxidase complex (Vectastain ABC Kit, Vector Laboratories) according to the manufacturer's instructions, then washed and developed with DAB.

In case of double labelling, fluorescent Alexa Fluor ${ }^{\mathrm{mm}}$ 488 goat anti-mouse secondary antibody was used for antigen ( $\beta$-catenin) detection, and streptavidin (Molecular Probes, Eugene, OR, USA, $568 \mathrm{~nm}$, red) for lectin (UEAI, HPA, WGA) demonstration.

\section{Transmission electron microscopy}

Samples of native tissue and 3D cultures were fixed in $3 \%$ buffered glutaraldehyde $(\mathrm{pH} 7.4)$ at $4^{\circ} \mathrm{C}$ for at least $12 \mathrm{hr}$, flushed three times with phosphate buffer, and post-fixed in $1 \% \mathrm{OsO}_{4}$ for $2 \mathrm{hr}$ at room temperature, followed by washing with phosphate buffer. Dehydration was performed in a series of graded ethanol solutions. Infiltration with propylene oxide was followed by increasing ratios of epoxy resin: propylene oxide (1:1, 3:1) and finally pure resin. After two additional changes, the resin was polymerized at $60^{\circ} \mathrm{C}$. Semithin sections $(0.7 \mu \mathrm{m})$ were stained with toluidine blue and embedded with DPX (Fluka, Buchs, Switzerland). Ultrathin sections were cut at $70 \mathrm{~nm}$, contrasted with alkaline-lead citrate and methanolic-uranyl acetate and viewed with a Zeiss EM 902 electron microscope and a SiS-software assisted CCD camera (Nikon).

\section{Scoring and statistical analysis}

The scoring of proliferative activity (anti-Ki-67 staining) as well as ER and PR expression was performed on two slides for each sample, counting in three different randomly-selected areas (40× magnification) using a light microscope with a Nikon DS-Fil digital camera system and Nikon NIS-Elements imaging and counting software (Nikon). The number of nuclei positive for the respective immunohistochemical staining was correlated to the total number of cells counted in that area. Glandular epithelial cells and stromal cells were counted separately. A minimum of 50 cells for cell culture samples, and 100 cells for native tissue samples were used per area.

The statistical analyses were performed using $\mathrm{IBM}^{\circ}$ SPSS $^{\bullet}$ Statistics 20 software. The assumption of normal distribution was tested using the Kolmogorov-Smirnov test. All data were normally distributed. Values are expressed as means \pm standard deviations (SD). To analyze the effects of time, medium and concentration on the expression of ER and PR as well as proliferative activity, a linear mixed model was performed appointing time and media as repeated measures. The significance of the differences between factor levels was determined using Bonferroni alpha correction as a post hoc procedure. For all analyses, a p-value $<0.05$ was considered significant.

\section{Results}

Histological and immunohistochemical evaluation of the native endometrial tissue

The canine uterine tissues used in this study for the 3D cell culture systems were classified as late metestrous $(n=3)$ and anestrous $(n=6)$ by means of histological and immunohistochemical assessment, including oestrogen and progesterone receptor expression (Figure 1) and proliferative activity (Figure 2).

\section{Histological and immunohistochemical evaluation of the 3D cultured endometrial glands and stromal cells}

H\&E-stained histological sections of the 3D-cultured glandular structures surrounded by stromal cells did not show any significant structural changes during the culture period of $48 \mathrm{hr}$. Luminal secretions appeared in all glandular structures indicating grossly correct physiological function of the glandular epithelial cells (Figure 3A).

To distinguish the phenotypes of the different isolated primary endometrial cell populations (glandular epithelial cells and stromal cells) as well as to examine the structural and functional characteristics of the cells, the expression of a series of key markers was assessed by means of immunohistochemistry.

Vimentin was used as a mesenchymal marker to identify stromal cells in the native tissue and the cultured endometrial structures, and to distinguish them from epithelial cells, which were used as an internal negative control (Figure 3B). Cytokeratin, used to characterize glandular epithelial cells, identified clear lumen formation and the cytoskeletal composition of the GECs without staining the stromal cells (Figure 3C). Laminin was used to assess the presence of the basement membrane surrounding the endometrial glands that is important for the tissue-specific structure and function correlated to the basolateral and apical polarization of the glandular epithelial cells (Figure 3D). Apical polarization of the 3D-cultured glandular epithelial cells was demonstrated by transmission electron microscopy (TEM), showing microvilli at the apical luminal region of the glandular epithelial cells and cell-cell contacts characteristic for glandular epithelial cells (tight junctions, zonula adhaerens, desmosomes) (Figure 3E).

Immunohistochemical anti $\beta$-catenin staining demonstrated the basolateral domains of the cell membranes of GECs, and was applied to detect $\beta$-catenin as a protein bound to the cytoplasmic domain of E-cadherin (Figure 3F). This protein complex is important for cell-to -cell adhesions, and this correlates with correct lumen formation of the GECs in vivo and in vitro. To demonstrate functional apical polarity of the glandular epithelial cells, different lectins (UEA I, HPA and WGA) were applied to analyse surface glycoconjugates. In contrast to 

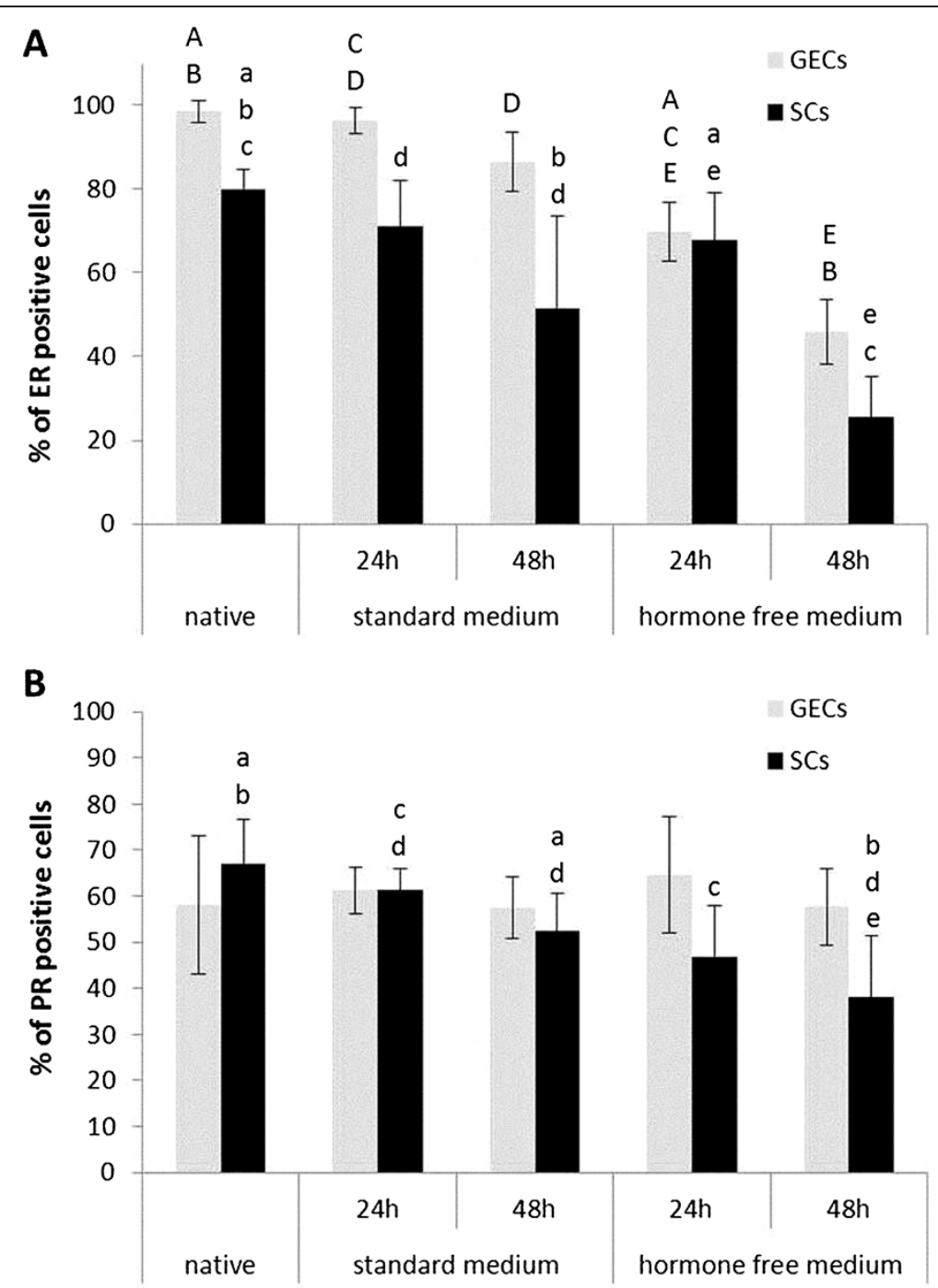

Figure 1 Estrogen and progesterone receptor expression in 3D cultured and native canine endometrial cells. Percentage of oestrogen receptor ER (A) and progesterone receptor PR (B) positive glandular epithelial cells (GECs) and stromal cells (SCs) in the canine uterine tissue of origin (native) as well as after 24 and $48 \mathrm{hr}$ of cell culture in standard medium and hormone free medium. Statistical significances $(p<0.05)$ are indicated as letters (A-E for GECs, a-e for SCS) above the related columns.

that of the other lectins, WGA-binding, with strong affinity to $\mathrm{N}$-acetylglucosamine sugar residues of the glycocalyx, remained stable during the whole culture period in the standard and hormone-free medium, and was therefore chosen to test the apical polarization of the glandular epithelial cells. Based on these results, a new double-staining method using $\beta$-catenin immunohistochemistry in combination with WGA lectin histochemistry was established in our laboratory to demonstrate apical and basolateral polarization of the 3D-cultured canine endometrial glandular structures (Figure 3G); this method showed the 3D-cultured structures to be comparable with those found in the native tissue (Figure $3 \mathrm{H}$ ).

The above-mentioned immunohistochemical markers were used as quality assurance for the cell-specific characteristics. The protein expression patterns of these markers did not show any alterations, either in the standard medium, or in any treatment group, compared to the original endometrial tissue during the whole culture period.

Staining patterns of nuclear oestrogen- and progesterone-receptors in the canine endometrial glandular epithelial and stromal cells cultured in standard medium (Figure 4A and 4B) were comparable to those in native uterine tissue samples (Figure $4 \mathrm{C}$ and 4D). Low proliferative activity, as demonstrated by immunohistochemical anti-Ki-67 staining, was detected in both 3D-cultured endometrial glands and stromal cells (Figure 4E) and glandular epithelium and stromal cells in native uterine tissue samples (Figure 4F). 


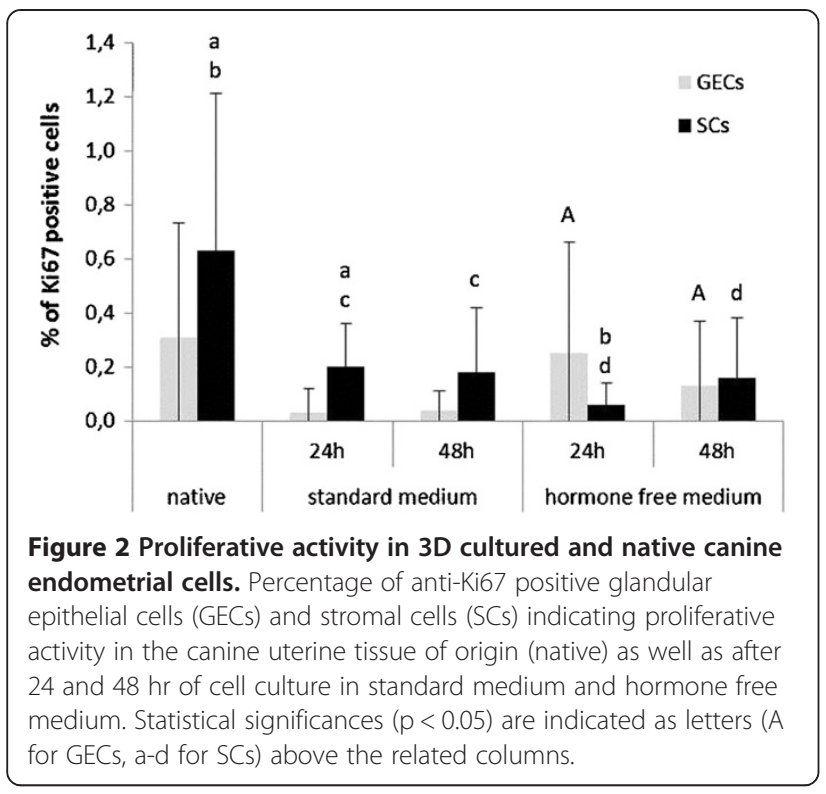

Scoring and statistical analysis of steroid hormone receptor expression and proliferative activity of endometrial glands and stromal cells in response to hormone supplementation in the 3D culture

Glandular structures and surrounding stromal cells cultured in standard medium for $24 \mathrm{hr}$ maintained their characteristic expression patterns concerning ER and PR comparable to the in vivo situation of the tissue of origin (Figure 1). After 48-hr culture in the standard medium, ERs of both cell types decreased, whereas PR expression was mainly reduced in SCs (Figure 1). Proliferative activity was below $1 \%$ in both standard medium cultured cells and in the native uterine tissue (Figure 2).

To exclude potential effects of the supplemented FCS, with its undefined components, the standard medium was filtered through a Sep-Pak C18 column to remove steroid-based molecules (hormone-free medium). ER expression patterns in GECs and SCs declined after $48 \mathrm{hr}$ culture in hormone-free conditions, whereas PRs declined only in SCs significantly (Figure 1). Proliferative activity was below $0.4 \%$ in both cell types after a $48-\mathrm{hr}$ hormone-free culture period (Figure 2). These hormonefree medium conditions were then used as baselines (control group) for testing the effects of steroid hormones on ER and PR expression, and on proliferative activity.

Effects of different concentrations of $17 \beta$-estradiol on ER and PR expression and proliferative activity of endometrial glands and stromal cells in 3D culture Different concentrations of $17 \beta$-estradiol (E) induced significant changes in the expression patterns of ER and $\mathrm{PR}$ in the 3D-cultured endometrial glandular epithelial cells and stromal cells during the 24- and 48-hr culture period compared to the control group (hormone free medium) (Figures 5A and 6A). E supplementation had a significant stimulatory effect on ERs in GECs in all concentrations. In SCs ER expression was reduced after treatment with $30 \mathrm{pg} / \mathrm{mL}$ E for $48 \mathrm{hr}$. PR expression in GECs increased after 24-hr culture time with $15 \mathrm{pg} / \mathrm{mL}$ and $100 \mathrm{pg} / \mathrm{mL} E$ but decreased due to supplementation of $30 \mathrm{pg} / \mathrm{mL} \mathrm{E}$ (Figure 6A). In SCs an increase of PRs was observed after $24 \mathrm{hr}$ in all of the treatment groups but after supplementation of $30 \mathrm{pg} / \mathrm{mL}$ E for $48 \mathrm{hr}$ PRs of the SCs declined compared to the control group (Figure 6A).

Beside the comparison with the control group significant results were also obtained between the different concentration groups of $E$ supplementation. The effects of the different concentrations of $\mathrm{E}$ on ER expression were mainly present in SCs with a significant reduction between 15 and $30 \mathrm{pg} / \mathrm{mL} \mathrm{E}(\mathrm{p}<0.01)$ and a significant increase of ER positive SCs between 30 to $100 \mathrm{pg} / \mathrm{mL} \mathrm{E}$ $(\mathrm{p}<0.01)$ after 48 -hr culturing period. Furthermore, PR expression in SCs was reduced after $48 \mathrm{hr}$ - treatment with $30 \mathrm{pg} / \mathrm{mL}$ E compared to the expression levels in SCs treated with $15(\mathrm{p}<0.01)$ and $100 \mathrm{pg} / \mathrm{mL} \mathrm{E}(\mathrm{p}<0.01)$, respectively, for the same culturing period.

The proliferative activities of GECs and SCs were assessed using an anti-Ki67 based assay. Although for both cell types an increase in Ki67-positive cells was measured following treatment with $30 \mathrm{pg} / \mathrm{mL}$ and $15 \mathrm{pg} / \mathrm{mL}$ E for $24 \mathrm{hr}$ compared to hormone-free cultured cells, a significant decrease in SCs was demonstrated with $100 \mathrm{pg} / \mathrm{mL}$ E (Figure 7A).

\section{Effects of different concentrations of progesterone on ER} and PR expression and proliferative activity of endometrial glands and stromal cells in 3D culture

The application of progesterone to 3D-cultured GECs and SCs induced significant changes in the expression patterns of the ER and PR during a 24-hr and 48-hr culture period compared to the control group, closely depending on the concentration of the supplemented $\mathrm{P}$ (Figures 5B and 6B).

In all concentrations $P$ had a stimulatory effect on ER expression in GECs compared to the control group (Figure 5B). In SCs an increase of PRs was observed after $3 \mathrm{ng} / \mathrm{mL}$ and $30 \mathrm{ng} / \mathrm{mL} \mathrm{P}$ treatment but due to supplementation of $15 \mathrm{ng} / \mathrm{mL}$ P PRs in SCs decreased. P had a reducing effect on PR expression in GECs after 24-hr culturing period compared to the control group, but after 48-hr culturing period PRs increased in GECs. In the SCs a reducing effect of only $15 \mathrm{ng} / \mathrm{mL} \mathrm{P}$ after $24 \mathrm{hr}$ treatment was observed followed by an increase of PRs in all treatment groups compared to the control group after $48 \mathrm{hr}$ culturing time (Figure 6B). 


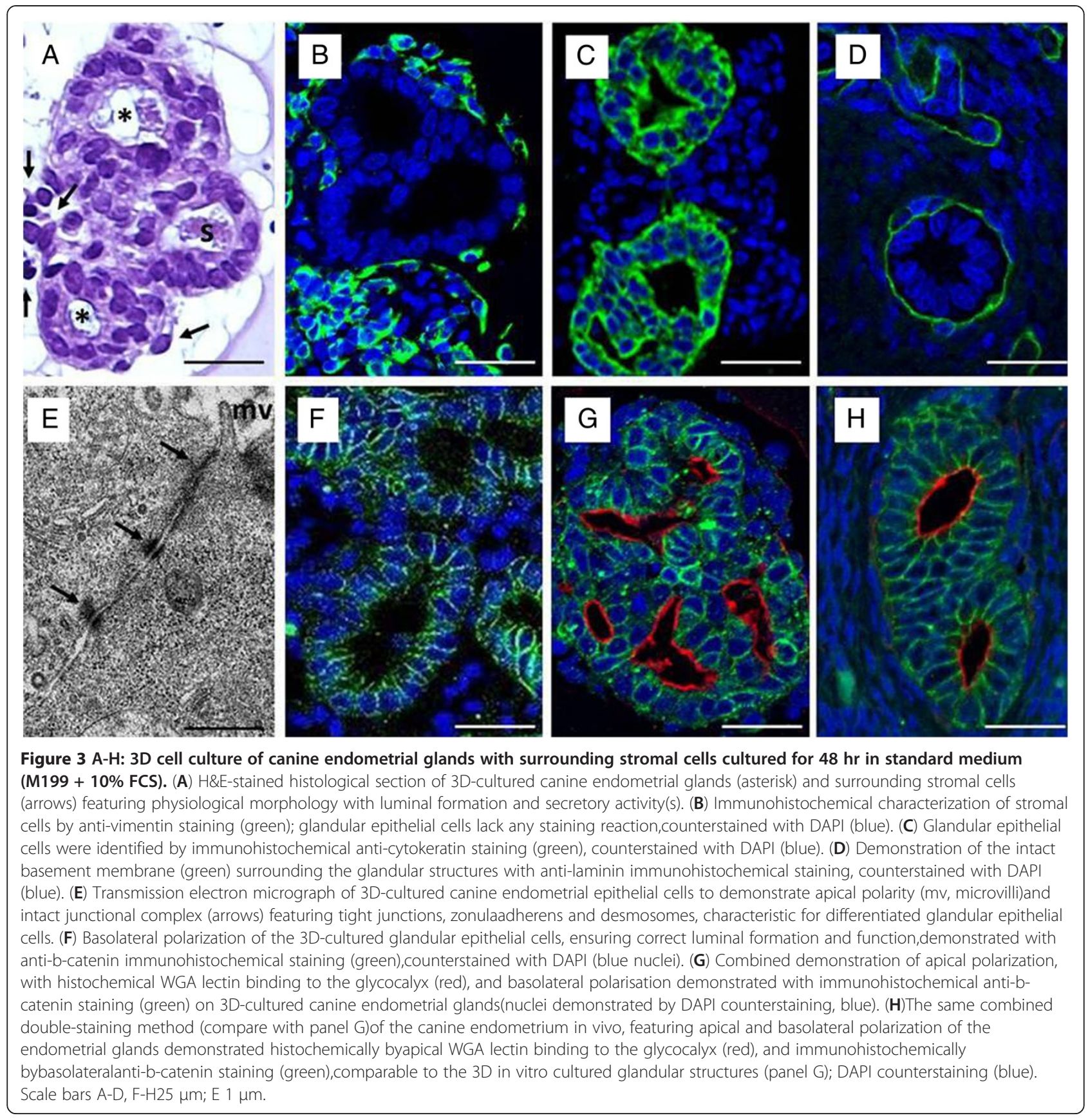

The clear dose dependent effects of P on ER expression in GECs were demonstrated by the reduction of ER positive GECs after $15 \mathrm{ng} / \mathrm{mL} \mathrm{P}$ treatment compared to the increased amounts of ER positive GECs after $3 \mathrm{ng} / \mathrm{mL}$ $\mathrm{P}(\mathrm{p}=0.016)$ and $30 \mathrm{ng} / \mathrm{mL} \mathrm{P}(\mathrm{p}=0.013)$, respectively, $24 \mathrm{hr}$-treatment. In the SCs ER expression was reduced due to supplementation of $15(\mathrm{p}<0.01)$ and $30 \mathrm{ng} / \mathrm{mL} \mathrm{P}$ $(\mathrm{p}=0.035)$, respectively, compared to the high expression levels in SCs with $3 \mathrm{ng} / \mathrm{mL} \mathrm{P}$ treatment after $24 \mathrm{hr}$ culturing period. After $48 \mathrm{hr}$-culturing period with $15 \mathrm{ng} / \mathrm{mL}$ P ERs in GECs were reduced compared to the 3 $(\mathrm{p}<0.01)$ and $30 \mathrm{ng} / \mathrm{mL} \mathrm{P}(\mathrm{p}=0.036)$ treatment. In SCs comparable results were obtained with a significant reduction of ERs after $48 \mathrm{hr}$ - culturing period with $15 \mathrm{ng} / \mathrm{mL} \mathrm{P}$ compared to $3(\mathrm{p}<0.01)$ and $30 \mathrm{ng} / \mathrm{mL} \mathrm{P}(\mathrm{p}<0.01)$, respectively. The high amount of ER positive SCs after $48 \mathrm{hr}$ - treatment with $30 \mathrm{ng} / \mathrm{mL}$ compared to $3 \mathrm{ng} / \mathrm{mL} \mathrm{P}$ $(\mathrm{p}<0.01)$ reflects the dose- and time-dependent reactions of SCs to P.

For all concentrations of $\mathrm{P}$, proliferative activity of GECs and SCs was below 1\%, but showed indication of a small enhancement, following treatment with $3 \mathrm{ng} / \mathrm{mL}$ 


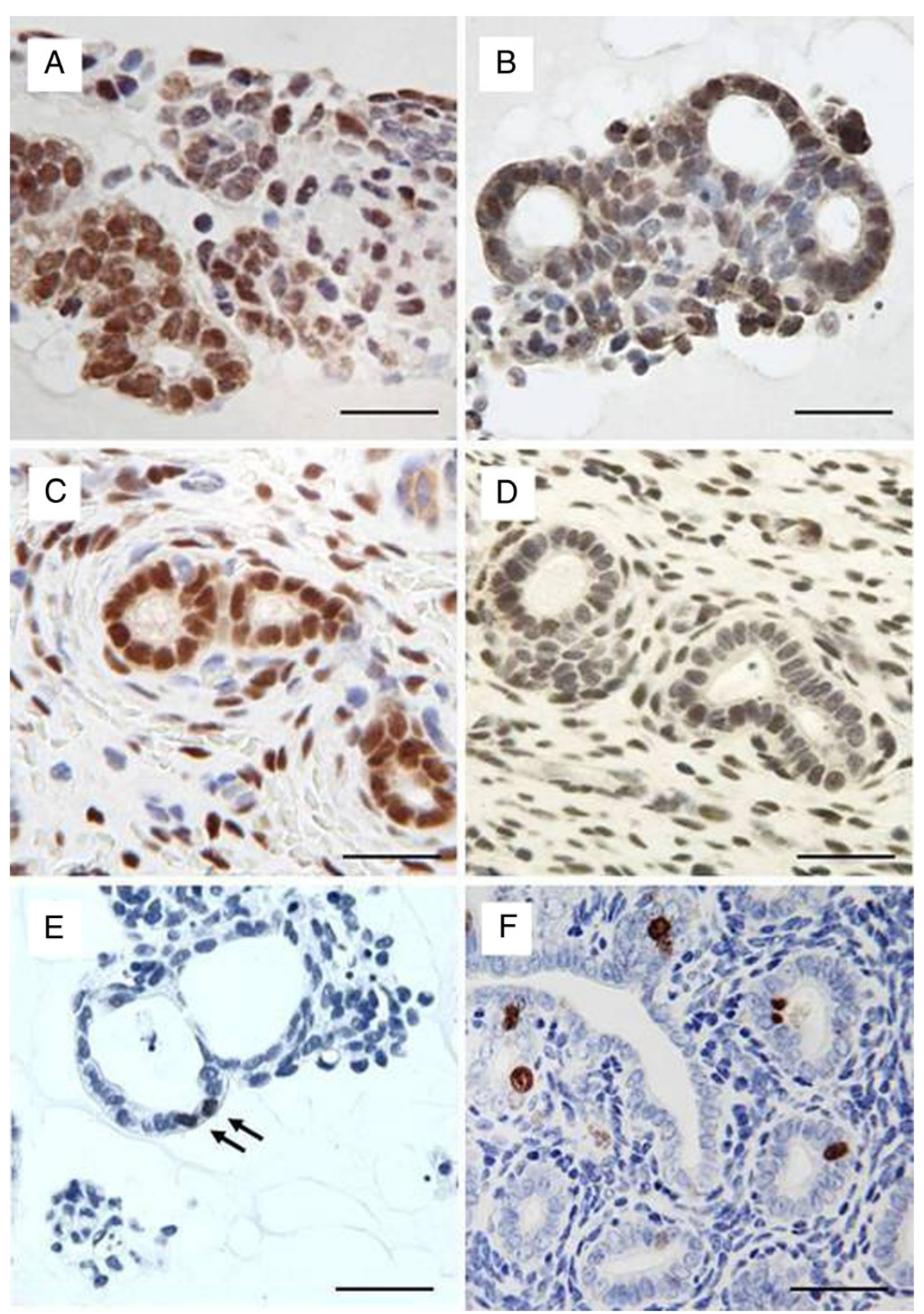

Figure 4 Immunohistochemical demonstration of oestrogen and progesterone receptorexpression and proliferative activityin 3D cell cultured canine endometrial cells compared to the native tissue. Oestrogen (A) and progesterone (B) receptor expression of glandular epithelial and stromal cells cultured for $48 \mathrm{hr}$ in standard mediumcompared to the native tissue (Coestrogen receptor, Dprogesterone receptor) indicated by immunohistochemical nuclear staining. Proliferative activity in 3D cell-cultured canine glandular epithelial cells (E) (arrows) compared to the in vivo situation (F) of uterine glands and surrounding stromal cells by means of anti-Ki67 immunohistochemical staining. Scale bars A-F, $25 \mu m$.

and $30 \mathrm{ng} / \mathrm{mL} \mathrm{P}$ for $24 \mathrm{hr}$, relative to the hormone-free medium controls (Figure 7B). SCs treated with $15 \mathrm{ng} / \mathrm{mL}$ $\mathrm{P}$ for $48 \mathrm{hr}$ showed a reduction in PR expression compared to the control group.

Detailed results, including all percentage values with their \pm SDs, are listed in Additional file 1: Table S1.

\section{Discussion}

The canine organotypic endometrial model features differentiated glandular structures with proper cell characteristics

The application of a 3D organotypic endometrial culture system using differentiated glandular structures and 

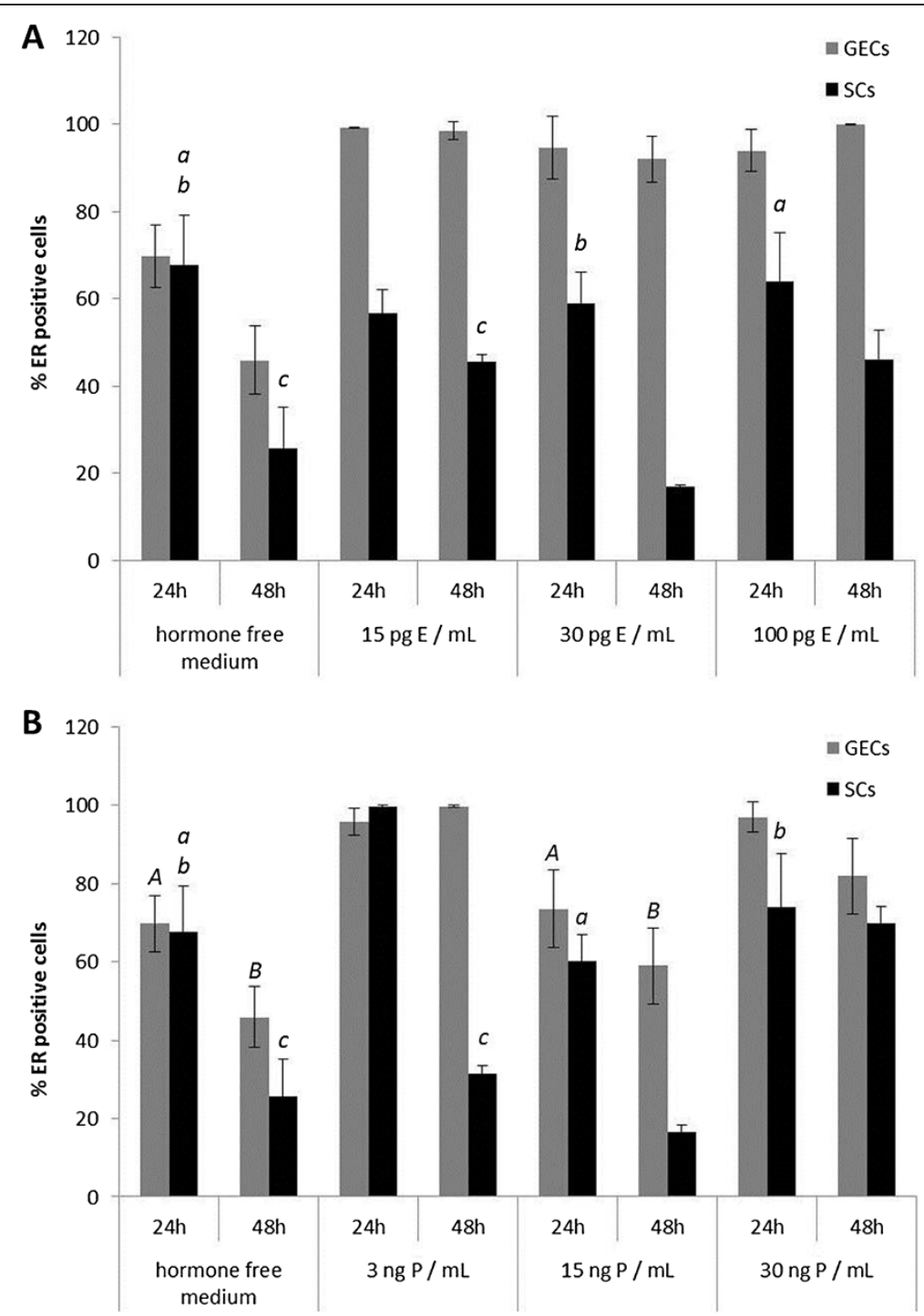

Figure 5 Alterations of oestrogen receptor expression in 3D cultured canine endometrial cells due to $17 \beta$-estradiol and progesterone supplementation. Percentage of oestrogen receptor ER positive glandular epithelial cells (GECs) and stromal cells (SCs) after 24 and 48 hr of 3D cell culture with (A) 17ß-estradiol supplementation (E) and (B) progesterone (P) in the respective three different concentrations. Due to the high number of statistical significant results concerning the comparison with the control group (hormone free) statistical non-significant ( $p>0.05)$ results are indicated as italic letters ( $A-B$ for GECs, a-e for SCs) above the related columns.

surrounding stromal cells, simulating their natural environment, provides a system closely mimicking the in vivo situation of the endometrium, and is well suited for the study of hormonal effects on a cellular level. It is well known that unphysiological cell culture conditions lead to significant alterations of cell characteristics. Galabova et al. [5] described vimentin expression in canine endometrial epithelial cells in vitro, a common phenomenon known for monolayer cell cultures [31]. This switch in cytoskeletal protein expression from epithelial cytokeratin to mesenchymal vimentin is most probably induced by the lack of a basal lamina, crucial for the formation of tissue-specific form and function [32] and epithelial polarization
$[10,32,33]$. In our 3D cell culture system neither changes in epithelial cytokeratin expression nor the disappearance of basal lamina structures were detected during the culture period, indicating that the glandular cells were fully differentiated. This underlines the preservation of the original basal lamina of the uterine glands, as ensured by our proto$\mathrm{col}$, as an essential factor. Furthermore, we tested different lectins (UEA I, HPA, WGA) for their suitability as markers for the correct apical polarization of the GECs, and we found WGA to be the most suitable lectin, labelling the apical cell membrane reliably. Similarly, Nacetylglucosamine has recently been reported to be present on the endometrial surface and glandular 


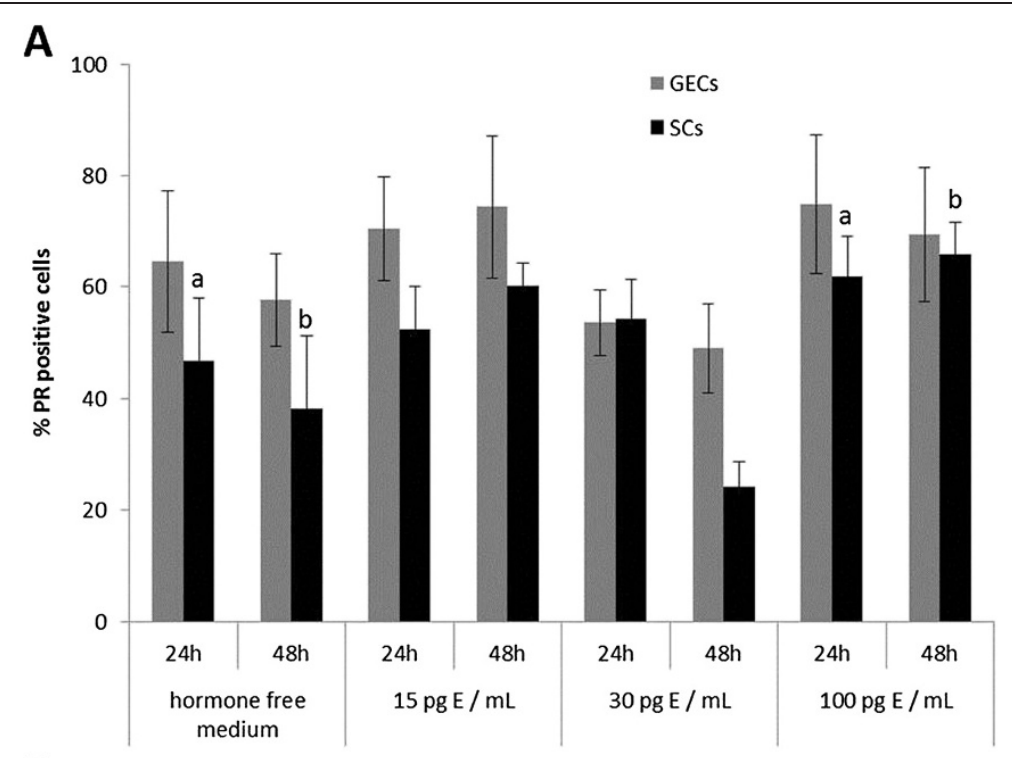

B

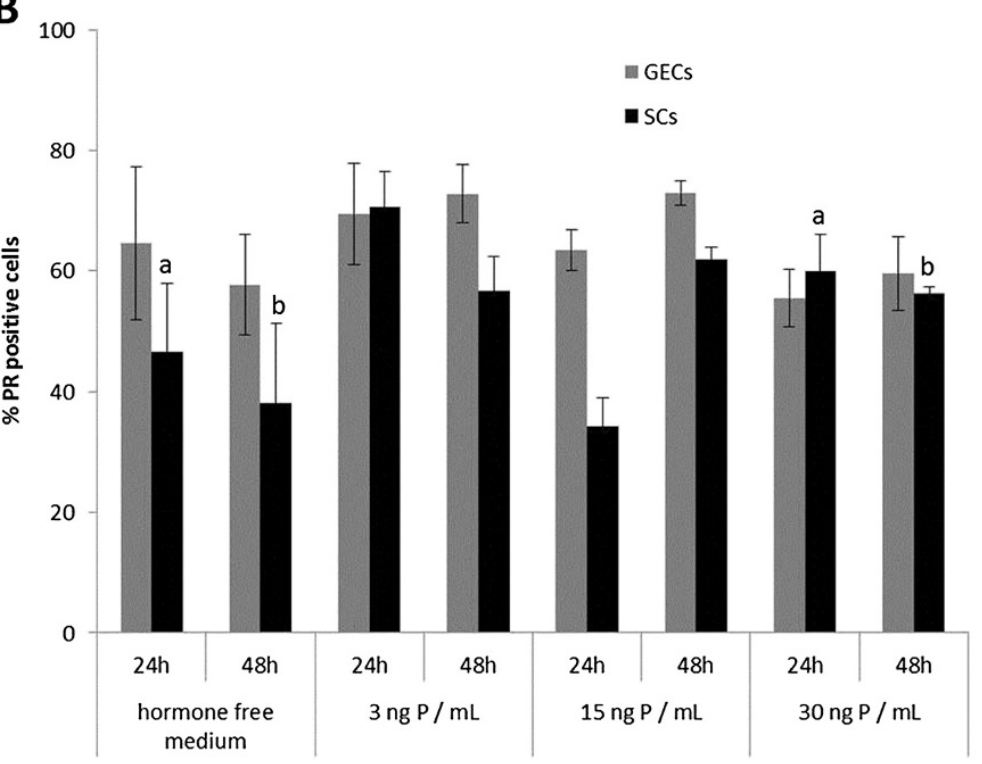

Figure 6 Alterations of progesterone receptor expression in 3D cultured canine endometrial cells due to $17 \beta$-estradiol and progesterone supplementation. Percentage of progesterone receptor PR positive glandular epithelial cells (GECs) and stromal cells (SCs) after 24 and $48 \mathrm{hr}$ of 3D cell culture with (A) 17ß-estradiol (E) and (B) progesterone (P) supplementation in the respective three different concentrations. Statistical significances $(p<0.05)$ are indicated as letters (A-E for GECs, a-e for SCs) above the related columns for comparison with the control group (hormone free medium).

epithelial cells during the physiological canine oestrous cycle as well as in pathological alterations of the uterine tissue [34]. Based on this knowledge and our results, we decided to use WGA as a marker for apical polarity of the glandular epithelial cells in our 3D cell culture system. Together with $\beta$-catenin we created a new double-labelling combination to assay apical and basolateral polarisation and using this were able to demonstrate the differentiation of cultured GECs in the 3D system. Loss of polarity is generally associated with increased proliferation and migration, two factors related to malignant alterations in tissues and dedifferentiation processes in monolayer or coculture systems of primary cells $[10,35]$.

In the 3D endometrial cell culture system ER and PR expression patterns in endometrial glands and stromal cells follow exogenous hormonal stimulation

In the dog, several studies have been performed to elucidate the specific effects of steroid hormones on the different cell types of the endometrium in vivo [36-38]. Even with progesterone concentrations at physiological levels, altered steroid hormone receptor expression 

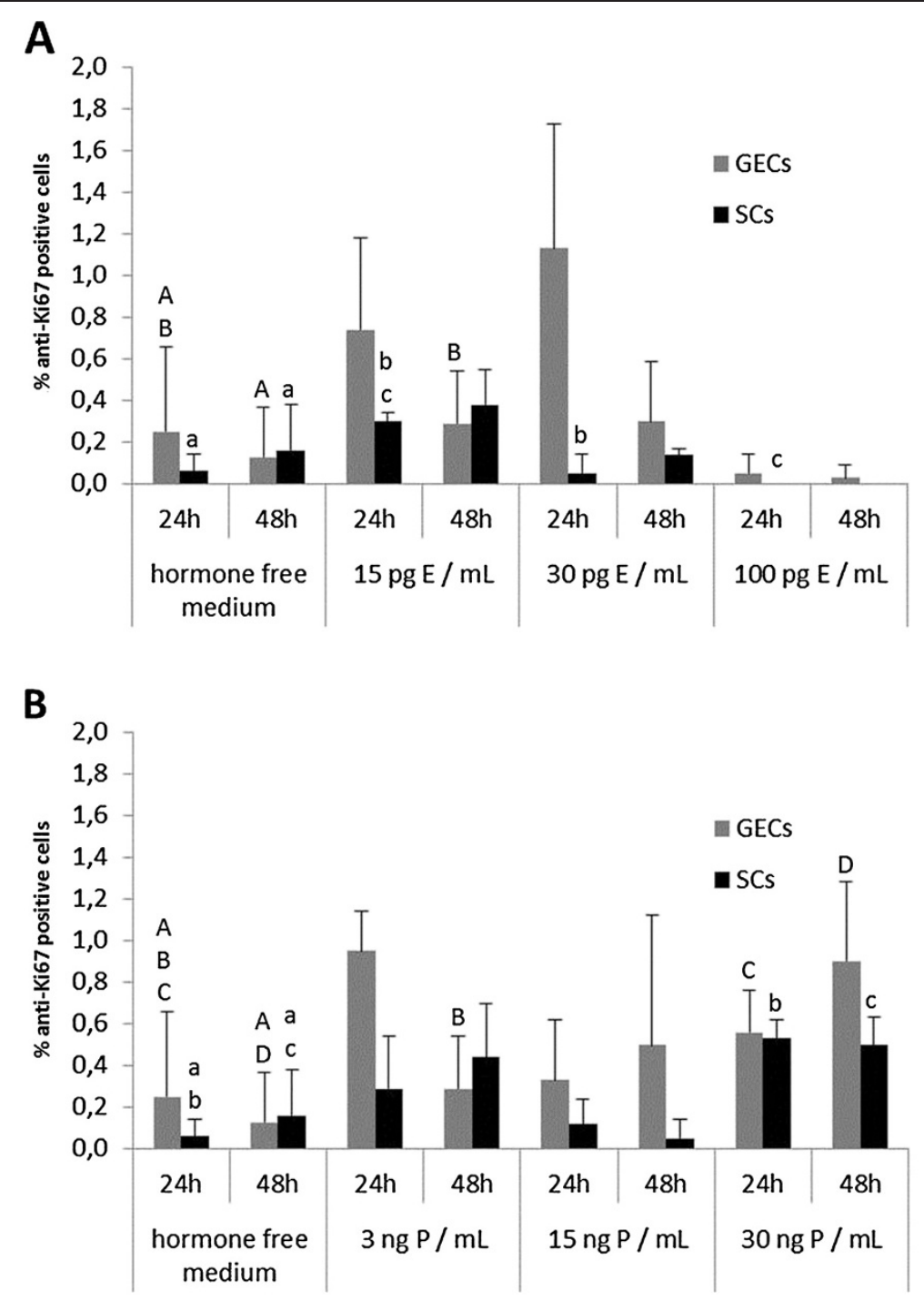

Figure 7 Alterations of proliferative activity in 3D cultured canine endometrial cells due to $17 \beta$-estradiol and progesterone supplementation. Percentage of anti-Ki67 positive glandular epithelial cells (GECs) and stromal cells (SCs) indicating proliferative activity after 24 and $48 \mathrm{hr}$ of 3D cell culture with (A) 17ß-estradiol (E) and (B) progesterone (P) supplementation in the respective three different concentrations. Statistical significances $(p<0.05)$ are indicated as letters (A-E for GECs, a-e for SCs) above the related columns.

patterns in the uterus are suggested to be involved in the pathogenesis of serious uterine diseases, such as cystic endometrial hyperplasia and pyometra $[1,3,39,40]$. Therefore, knowledge about the direct effects of different progesterone and oestrogen concentrations on endometrial epithelial and stromal cells could help the understanding of physiological and pathological processes in the endometrium.

Compared to the initial situation of ER and PR status in the uterus, ER expression of GECs and SCs declined after a $48 \mathrm{hr}$ hormone-free culture period, whereas PR expression was nearly stable in GECs and declined only in SCs. These effects were also observed in extenuated patterns in standard medium. We interpret this observation as a response to the lack of a stimulus under these culture conditions. Consistent with our observations, Pierro et al. [41] described altered ER expression patterns and responsiveness of human endometrial epithelial and stromal cells to $\mathrm{E}$ in vitro as a result of missing paracrine factors (e.g. insulin).

The application of different physiological concentrations of steroid hormones according to the canine oestrous cycle $[42,43]$ demonstrated the capability of the endometrial GECs and SCs to respond to these supplements in an organotypic endometrial cell culture model. In our 3D cell culture system addition of $E$ resulted in increased ER expression in GECs $(100 \mathrm{pg} / \mathrm{mL}$ and $15 \mathrm{pg} / \mathrm{mL} \mathrm{E}$ ), but this was decreased in SCs with a 
minimum level following $30 \mathrm{pg} / \mathrm{mL} \mathrm{E}$ for $48 \mathrm{hr}$. These results are at least in part comparable with the physiological situation. In the native canine endometrial tissue ER expression in GECs is high in proestrus (E $5-10 \mathrm{pg} / \mathrm{mL}$; P $0.2-0.4 \mathrm{ng} / \mathrm{mL}$ ), and oestrus (E $20-80 \mathrm{pg} / \mathrm{mL}$, P $1-5 \mathrm{ng} / \mathrm{mL}$ ) but decreasing during early metestrus (E $10-25 \mathrm{pg} / \mathrm{mL}, \mathrm{P} 15-80 \mathrm{ng} / \mathrm{mL}$ ) [43]. SCs follow the same scheme but with more pronounced fluctuations as reported before [28]. Compared to the anestrous ER expression in SCs a decline during oestrus and early metestrus but an increase during early proestrus was reported by Dhaliwal et al. [44] and Veremirsch et al. [28] in the native canine endometrium. Therefore, the reduction of ERs in SCs due to $30 \mathrm{pg} / \mathrm{mL}$ E (comparable to estrous/early metestrous plasma $\mathrm{E}$ levels) appears to be analogous to the in vivo situation.

In the monolayer culture system of canine endometrial cells ERs in both cell types increased due to $100 \mathrm{pg} / \mathrm{mL}$ $\mathrm{E}$ [5]. This reaction of SCs may be a result of separated single cell-type culturing in a $2 \mathrm{D}$ cell culture system due to a lack of interactions between stromal and epithelial cells. Haslam et al. [20] demonstrated that in the mammary gland oestrogenic effects on glandular epithelial cells are controlled by mammary stromal cells in vivo and in vitro [45]. Direct supplementation of $\mathrm{E}$ to mammary epithelial cells cultured alone did not show any effects, neither morphological nor pro-proliferative, although ERs were expressed in these epithelial cells [46]. Pierro et al. [41] were able to induce an E dosedependent increase in proliferative activity in human endometrial epithelial cells only when these were cocultured with endometrial stromal cells, underlining the importance of epithelial-stromal signaling in hormonal transduction.

PR expression in the GECs was reduced in our 3D cell culture system following E supplementation $(100 \mathrm{pg} / \mathrm{mL}$ and $30 \mathrm{pg} / \mathrm{mL}$ E) but increased with $15 \mathrm{pg} / \mathrm{mL}$ E for 48 hr. In the native endometrium PR expression in the GECs is high during early proestrus and oestrus but declines during early and late metestrus compared to anestrous levels $[12,44]$. PR expression in SCs in vitro increased following supplementation of $15 \mathrm{pg} / \mathrm{mL}$ and $100 \mathrm{pg} / \mathrm{mL}$ E, but decreased after treatment with $30 \mathrm{pg} / \mathrm{mL}$ $\mathrm{E}$ for $48 \mathrm{hr}$. PR expression in SCs in vivo declines from early to late metestrus compared to anestrous levels, but increases during early proestrus to reach anestrous levels during oestrus $[12,44]$. The achieved results demonstrate that the two different cell types of the 3D cell culture system partially react comparable to the normal canine endometrial tissue. The increase of PR-positive GECs in the 3D cell culture system upon treatment with $15 \mathrm{pg} / \mathrm{mL}$ $\mathrm{E}$ is comparable to the increase of PR expression during proestus/early oestrus, and the decline of PR expression in $\mathrm{SCs}$ with $30 \mathrm{pg} / \mathrm{mL} \mathrm{E}$ in vitro mirrors the effects during early metestrus in vivo. In a human endometrial coculture system, addition of $\mathrm{E}$ induced increased PRpositive immunoreactivity of endometrial epithelial cells [47]. Comparable results were observed in the murine endometrium model of Chung et al. [48], demonstrating an increase of PR expression in co-cultured endometrial epithelial cells due to E supplementation. In both studies, endometrial epithelial cells were separated by membranes (inserts) from the stromal cells. In contrast to our 3D organotypic endometrial model neither physiological glandular architecture nor contact between stromal and epithelial cells was provided. Bläuer et al. [47] used epithelial organoids embedded in Matrigel ${ }^{\mathrm{Tx}}$, which formed glandular structures within $24 \mathrm{hr}$, to show the positive response of epithelial PRs to $\mathrm{E}$ supplementation. The decrease of PRs in our studies after treatment with $100 \mathrm{pg} / \mathrm{mL}$ and $30 \mathrm{pg} / \mathrm{mL} \mathrm{E}$ in GECs and $30 \mathrm{pg} / \mathrm{mL} \mathrm{E}$ in $\mathrm{SCs}$, in contrast to the positive regulation of PRs in GECs and SCs following $15 \mathrm{pg} / \mathrm{mL} \mathrm{E}$ after $48 \mathrm{~h}$ culturing period, may reflect the importance of tissue composition (cell-cell contacts) on the one hand, and may display caninespecific reactions of GECs and SCs to the supplemented hormones on the other. Interpretation of species-specific reactions to supplemented steroid hormones in co-culture or 3D-culture systems has to be carried out carefully because of the different culture techniques and ECM compositions.

Another important fact concerning endometrial ER and PR expression patterns in GECs and SCs in the native canine endometrium is that, especially for PRs, different regions of the glands have to be considered due to the different expression patterns of PRs. Vermeirsch et al. [12] described distinct PR expression of the basal portion of endometrial glands and their glandular ducts reaching to the surface epithelium. Due to our extraction technique that obtains intact endometrial glands, these regions are no longer distinguishable in the histological sections, and furthermore we do not know if the loss of contact to the surface epithelium induces additional changes of PR (and ER) expression patterns. Nevertheless, we are convinced that working with isolated primary endometrial glands more closely resembles the physiological situation than working with secondary constructed spheroids [10].

The effects of $\mathrm{P}$ in the 3D cell-culture system were demonstrated in a decline of ERs in GECs and SCs due to supplementation of $15 \mathrm{ng} / \mathrm{mL}$ P for $48 \mathrm{hr}$. Supplementation of $3 \mathrm{ng} / \mathrm{mL} \mathrm{P}$ for $48 \mathrm{hr}$ led to a reduction of ER-positive SCs, whereas GECs showed a minimal increase of ER expression after $48 \mathrm{hr}$ in culture. Different authors $[13,28]$ reported that ER expression patterns in the native canine endometrium showed declining values due to increasing serum P levels during oestrus. Increasing ER expression accompanied in vivo decreasing serum 
$\mathrm{P}$ values (below $1 \mathrm{ng} / \mathrm{mL}$ ) during late metestrus were observed in GECs after treatment with $3 \mathrm{ng} / \mathrm{mL} \mathrm{P}$. In contrast, in the 2D cell culture system of Galabova et al. [5] ER expression in co-cultured GECs was reduced following $3 \mathrm{ng} / \mathrm{mL} \mathrm{P}$. In the human endometrial cell culture model of Classen Linke et al. [49] endometrial epithelial and stromal cells showed significant downregulation of ER and PR expression following gestagen supplementation. Similarly Bläuer et al. [47] demonstrated reduced PR expression in epithelial organoids after medroxyprogesterone acetate supplementation, to an undetectable level. PR expression in our 3D-cultured SCs increased after $24 \mathrm{hr}$ supplementation with $30 \mathrm{ng} / \mathrm{mL} \mathrm{P}$ (compared to the hormone free cultivated control group), comparable to the increase of PR expression in SCs at the end of oestrus or early metestrus. These discrepancies with other endometrial epithelial cell cultures may be explained by species-specific reactions of endometrial GECs and SCs, corroborated by the fact that the prolonged serum $\mathrm{P}$ levels in the bitch during metestrous are unique to canids $[43,50]$.

\section{Proliferative activity of endometrial glands and stromal cells in the 3D cell culture system show minor reactions to the added steroid hormones}

As the proliferative activity of GECs and SCs in the standard medium was below $1 \%$ and of GECs and SCs in the hormone-free medium below $0.2 \%$ after a 48 -hr culture period, high SD values were inevitably produced from the statistical analysis. In the basal glands of the native canine endometrium, proliferative activity is at low levels in proestrus, with values rapidly increasing in oestrus and early metestrus, followed by declining values in late metestrus and anestrus [15]. Neither in the canine monolayer endometrial culture system [5] nor in our 3D cell-culture system were clear effects of $\mathrm{E}$ on proliferative activity observed.

However, supplementation of $30 \mathrm{ng} / \mathrm{mL} \mathrm{P}$ for $24 \mathrm{hr}$ induced a significant rise in proliferative activity in GECs and SCs in the 3D cell-culture system, compared to the hormone-free cultured cells. Comparable effects of low doses of $\mathrm{P}$ were observed in the $2 \mathrm{D}$ cell-culture system of Galabova et al. [5]. In the native canine endometrial tissue, proliferative activity of the stromal cells is highest in proestrus under oestrogenic influence, and decreases during oestrus with increasing plasma P levels [15]. These divergent reactions of the cells to the steroid hormones in vitro concerning proliferative activity compared to the in vivo situation may be a result of the single use of either E or P. For example, in the murine endometrium model of Chang et al. [48] P supplementation alone did not show any effects on the proliferative activity of SCs, but in combination with $\mathrm{E}$ it had inhibitory effects on E-induced proliferative activity. It has to be considered that in the (canine) endometrium, different cell populations (surface and glandular epithelial cells, epithelial cells of the crypts as well as stromal cells and endothelial cells) in different regions (surface, basal region) show different patterns of proliferative activity during the individual cyclic phases. Van Cruchten et al. [15] described increased mitotic activity of the surface epithelium, the stroma, the blood vessels and the crypts during proestrus, whereas for the basal glands, proliferative activity increased during oestrus compared to late metestrus and anestrus. In the basal endometrial glands a positive correlation of serum $\mathrm{P}$ levels and proliferative activity were observed, whereas in the other cell groups this activity positively correlated with levels of E. Van Cruchten et al. [15] concluded that regulation of the proliferation in the canine endometrial surface epithelium, the stroma, the blood vessels and the crypts is different from that in the basal glands. These results highlight the problems faced by researchers isolating, and subsequently culturing and analyzing, isolated endometrial glands and stromal cells originating from the different endometrial regions.

\section{Conclusions}

We have been able to demonstrate the advantages of a $3 \mathrm{D}$ cell-culture model of the canine endometrium over monolayer cultures, for experimental approaches due to the differentiated and polarized cell conditions. We found pronounced effects due to single steroid hormone supplementation on ER and PR expression in epithelial and stromal cells. However, in the bitch the prolonged $\mathrm{P}$ phase during metestrous as well as the importance of the E:P ratio for the sensitive balance of steroid hormone receptor expression are unique scenarios, and therefore the mimicry of this special hormonal situation in the cycling canine endometrium deserves particular consideration in further studies.

\section{Additional file}

Additional file 1: Table S1. Detailed scoring results for expression of
estrogen and progesterone receptors and proliferative activity in
glandular epithelial cells (GECs) and stromal cells (SCS) during different
culturing media (standard and hormone free medium as well as
supplemented estrogen E and progesterone P in different dosages for 24
and 48 hours, respectively); all values are listed as percentage values $\pm S D$.

\section{Abbreviations}

3D: Three dimensional; DAPI: 4',6-Diamidin-2-phenylindol; DPBS$A B$ : Dulbecco's Phosphate Buffered Saline containing antibiotics; E: oestrogen (17 $\beta$-estradiol); ECM: Extracellular matrix; ER: Oestrogen receptor; FCS: Fetal calf serum; GEC: Glandular epithelial cell; HPA: Helix Pomatia Agglutinin; P: Progesterone; PR: Progesterone receptor; SC: Stromal cell; SD: Standard deviations; TEM: Transmission electron microscopy; UEA: Ulex Europaeus Agglutinin; WGA: Wheat Germ Agglutinin. 


\section{Competing interests}

The authors declare that they have no competing interests.

\section{Authors' contributions}

CB conceived the study, performed cell culture experiments, histological, histochemical and immunohistochemical as well as transmission electron microscopy evaluation, and drafted the manuscript. TA participated in the design of the study regarding statistical analyses, and helped to draft the statistical part of the manuscript. SS provided the tissue samples, prepared clinical anamneses and cycle determination of the animals, and revised the manuscript. CA participated in the study design and revised the manuscript IW conceived the study, participated in the study design and coordination, and helped to draft the manuscript. All authors read and approved the final manuscript.

\section{Acknowledgements}

Part of this study was performed within the framework of the Initiative Doctoral College BIOREC (Biological Responses to Environmental Challenges) programme of the University of Veterinary Medicine of Vienna. The expert technical assistance of Magdalena Helmreich, Stefanie Burger, Waltraud Tschulenk, Floriane Schaub, Brigitte Machac and Anne Flemming as well as the biochemical input concerning steroid hormones of Prof. Dr. Erich Möstl is greatly acknowledged. We also thank James Hutchins for editing the scientific English of the manuscript.

\section{Author details}

${ }^{1}$ Department of Pathobiology, Institute of Anatomy, Histology and Embryology, University of Veterinary Medicine, Veterinaerplatz 1, Vienna A - 1210, Austria. ${ }^{2}$ Department of Biomedical Science, Institute of Population Genetics, Platform Biostatistics, University of Veterinary Medicine, Veterinaerplatz 1, Vienna A - 1210, Austria. ${ }^{3}$ Small Animal Practice, Vienna 1220, Austria. ${ }^{4}$ Centre for Artificial Insemination and Embryo Transfer, University of Veterinary Medicine, Veterinaerplatz 1, Vienna A - 1210, Austria. ${ }^{5}$ VetCore Facility for Research, University of Veterinary Medicine, Veterinaerplatz 1, Vienna A - 1210, Austria.

Received: 27 August 2012 Accepted: 22 April 2013

Published: 24 April 2013

\section{References}

1. Noakes DE, Dhaliwal GK, England GC: Cystic endometrial hyperplasia/ pyometra in dogs: a review of the causes and pathogenesis. J Reprod Fertil Suppl 2001, 57:395-406.

2. De Bosschere $H$, Ducatelle R, Vermeirsch H, Van Den Broeck W, Coryn M: Cystic endometrial hyperplasia-pyometra complex in the bitch: should the two entities be disconnected? Theriogenology 2001, 55(7):1509-1519.

3. De Cock H, Vermeirsch H, Ducatelle R, De Schepper J: Immunohistochemical analysis of estrogen receptors in cysticendometritis-pyometra complex in the bitch. Theriogenology 1997, 48(6):1035-1047.

4. Stadler K, Handler J, Schoenkypl S, Walter I: A three-dimensional culture model of canine uterine glands. In Vitro Cell Dev Biol Anim 2009, 45(1-2):35-43.

5. Galabova-Kovacs G, Walter I, Aurich C, Aurich JE: Steroid receptors in canine endometrial cells can be regulated by estrogen and progesterone under in vitro conditions. Theriogenology 2004, 61(5):963-976.

6. Blow N: Cell culture: building a better matrix. Nat Meth 2009, 6(8):619-622.

7. Cukierman E, Pankov R, Yamada KM: Cell interactions with threedimensional matrices. Curr Opin Cell Biol 2002, 14(5):633-639.

8. Abbott A: Cell culture: biology's new dimension. Nature 2003, 424(6951):870-872.

9. Birgersdotter A, Sandberg R, Ernberg I: Gene expression perturbation in vitro-a growing case for three-dimensional (3D) culture systems. Semin Cancer Biol 2005, 15(5):405-412.

10. Inman $J$, Bissell MJ: Apical polarity in three-dimensional culture systems: where to now? J Biol 2010, 9(1):2

11. Vermeirsch $H$, Van den Broeck W, Coryn M, Simoens P: Immunohistochemical detection of androgen receptors in the canine uterus throughout the estrus cycle. Theriogenology 2002, 57(9):2203-2216.
12. Vermeirsch $H$, Simoens $P$, Hellemans $A$, Coryn $M$, Lauwers $H$ : Immunohistochemical detection of progesterone receptors in the canine uterus and their relation to sex steroid hormone levels. Theriogenology 2000, 53(3):773-788.

13. Johnston SD, Kiang DT, Seguin BE, Hegstad RL: Cytoplasmic estrogen and progesterone receptors in canine endometrium during the estrous cycle. Am J Vet Res 1985, 46(8):1653-1658.

14. Galabova G, Egerbacher M, Aurich JE, Leitner M, Walter I: Morphological changes of the endometrial epithelium in the bitch during metoestrus and anoestrus. Reprod Domest Anim 2003, 38(5):415-420.

15. Van Cruchten S, Van den Broeck W, D'Haeseleer M, Simoens P: Proliferation patterns in the canine endometrium during the estrous cycle. Theriogenology 2004, 62(3-4):631-641.

16. Barrau MD, Abel JH Jr, Verhage HG, Tietz WJ Jr: Development of the endometrium during the estrous cycle in the bitch. Am J Anat 1975 142(1):47-65.

17. Hebner C, Weaver VM, Debnath J: Modeling morphogenesis and oncogenesis in three-dimensional breast epithelial cultures. Annu Rev Pathol 2008, 3:313-339.

18. Lee GY, Kenny PA, Lee EH, Bissell MJ: Three-dimensional culture models of normal and malignant breast epithelial cells. Nat Methods 2007, 4(4):359-365.

19. Debnath J, Brugge JS: Modelling glandular epithelial cancers in threedimensional cultures. Nat Rev Cancer 2005, 5(9):675-688.

20. Haslam SZ, Woodward TL: Host microenvironment in breast cancer development: epithelial-cell-stromal-cell interactions and steroid hormone action in normal and cancerous mammary gland. Breast Cancer Res 2003, 5(4):208-215.

21. Grun B, Benjamin E, Sinclair J, Timms JF, Jacobs IJ, Gayther SA, Dafou D: Three-dimensional in vitro cell biology models of ovarian and endometrial cancer. Cell Prolif 2009, 42(2):219-228.

22. Kim JB: Three-dimensional tissue culture models in cancer biology. Semin Cancer Biol 2005, 15(5):365-377.

23. Kunz-Schughart LA, Groebe K, Mueller-Klieser W: Three-dimensional cell culture induces novel proliferative and metabolic alterations associated with oncogenic transformation. Int J Cancer Journal international du cancer 1996, 66(4):578-586.

24. Allen RL, Wright RW Jr: In vitro development of porcine embryos in coculture with endometrial cell monolayers or culture supernatants. J Anim Sci 1984, 59(6):1657-1661.

25. Yamauchi N, Yamada O, Takahashi T, Imai K, Sato T, Ito A, Hashizume K: A three-dimensional cell culture model for bovine endometrium: regeneration of a multicellular spheroid using ascorbate. Placenta 2003, 24(2-3):258-269.

26. Korff T, Augustin HG: Integration of endothelial cells in multicellular spheroids prevents apoptosis and induces differentiation. J Cell Biol 1998, 143(5):1341-1352.

27. Mulisch Maria WU: Romeis Mikroskopische Technik. 18th edition. Spektrum Akademischer Verlag Heidelberg: Imprint Springer; 2010.

28. Vermeirsch $H$, Simoens $P$, Lauwers $H$, Coryn M: Immunohistochemical detection of estrogen receptors in the canine uterus and their relation to sex steroid hormone levels. Theriogenology 1999, 51(4):729-743.

29. Mostl E, Brunner I: Comparison of different progestagen assays for measuring progesterone metabolites in faeces of the bitch. Zentralb/ Veterinarmed A 1997, 44(9-10):573-578.

30. Bartel C, Schonkypl S, Walter I: Pseudo-placentational endometrial cysts in a bitch. Anat Histol Embryol 2010, 39(1):74-80.

31. Classen-Linke I, Kusche M, Knauthe R, Beier HM: Establishment of a human endometrial cell culture system and characterization of its polarized hormone responsive epithelial cells. Cell Tissue Res 1997, 287(1):171-185.

32. Petersen OW, Ronnov-Jessen L, Howlett AR, Bissell MJ: Interaction with basement membrane serves to rapidly distinguish growth and differentiation pattern of normal and malignant human breast epithelial cells. Proc Natl Acad Sci USA 1992, 89(19):9064-9068.

33. Streuli $\mathrm{CH}$, Bailey N, Bissell MJ: Control of mammary epithelial differentiation: basement membrane induces tissue-specific gene expression in the absence of cell-cell interaction and morphological polarity. J Cell Biol 1991, 115(5):1383-1395.

34. Leitner M, Aurich JE, Galabova G, Aurich C, Walter I: Lectin binding patterns in normal canine endometrium and in bitches with pyometra and cystic endometrial hyperplasia. Histol Histopathol 2003, 18(3):787-795. 
35. Eritja N, Llobet D, Domingo M, Santacana M, Yeramian A, Matias-Guiu X, Dolcet X: A novel three-dimensional culture system of polarized epithelial cells to study endometrial carcinogenesis. Am J Pathol 2010, 176(6):2722-2731.

36. Buhi WC, Thatcher MJ, Shille VM, Alvarez IM, Lannon AP, Johnson J: Synthesis of uterine endometrial proteins during early diestrus in the cyclic and pregnant dog, and after estrogen and progesterone treatment. Biol Reprod 1992, 47(3):326-336.

37. Chu PY, Lee CS, Moore PF, Wright PJ: Oestrogen and progestagen treated ovariectomized bitches: a model for the study of uterine function. J Reprod Fertil Suppl 2001, 57:45-54.

38. De Bosscher H, Ducatelle R, Tshamala M, Coryn M: Changes in sex hormone receptors during administration of progesterone to prevent estrus in the bitch. Theriogenology 2002, 58(6):1209-1217.

39. Dhaliwal GK, England GC, Noakes DE: Oestrogen and progesterone receptors in the uterine wall of bitches with cystic endometrial hyperplasia/pyometra. Vet Rec 1999, 145(16):455-457.

40. Smith FO: Canine pyometra. Theriogenology 2006, 66(3):610-612.

41. Pierro E, Minici F, Alesiani O, Miceli F, Proto C, Screpanti I, Mancuso S, Lanzone A: Stromal-epithelial interactions modulate estrogen responsiveness in normal human endometrium. Biol Reprod 2001, 64(3):831-838.

42. Jeffcoate IA, Lindsay FE: Ovulation detection and timing of insemination based on hormone concentrations, vaginal cytology and the endoscopic appearance of the vagina in domestic bitches. J Reprod Fertil Supp/ 1989, 39:277-287.

43. Concannon PW: Reproductive cycles of the domestic bitch. Anim Reprod Sci 2011, 124(3-4):200-210.

44. Dhaliwal GK, England GC, Noakes DE: Immunocytochemical localization of oestrogen and progesterone receptors in the uterus of the normal bitch during oestrus and metoestrus. J Reprod Fertil Suppl 1997, 51:167-176.

45. Woodward TL, Xie JW, Haslam SZ: The role of mammary stroma in modulating the proliferative response to ovarian hormones in the normal mammary gland. J Mammary Gland Biol Neoplasia 1998, 3(2):117-131.

46. Zhang HZ, Bennett JM, Smith KT, Sunil N, Haslam SZ: Estrogen mediates mammary epithelial cell proliferation in serum-free culture indirectly via mammary stroma-derived hepatocyte growth factor. Endocrinology 2002, 143(9):3427-3434

47. Blauer M, Heinonen PK, Martikainen PM, Tomas E, Ylikomi T: A novel organotypic culture model for normal human endometrium: regulation of epithelial cell proliferation by estradiol and medroxyprogesterone acetate. Hum Reprod 2005, 20(4):864-871.

48. Chung D, Das SK: Mouse primary uterine cell coculture system revisited: ovarian hormones mimic the aspects of in vivo uterine cell proliferation. Endocrinology 2011, 152(8):3246-3258.

49. Classen-Linke I, Alfer J, Hey S, Krusche CA, Kusche M, Beier HM: Marker molecules of human endometrial differentiation can be hormonally regulated under in-vitro conditions as in-vivo. Hum Reprod Update 1998, 4(5):539-549.

50. Concannon PW, Castracane VD, Temple M, Montanez A: Endocrine control of ovarian function in dogs and other carnivores. Anim Reprod 2009, 6(1):172-193.

doi:10.1186/1746-6148-9-86

Cite this article as: Bartel et al.: Effects of steroid hormones on differentiated glandular epithelial and stromal cells in a three dimensional cell culture model of the canine endometrium. BMC Veterinary Research 2013 9:86.

\section{Submit your next manuscript to BioMed Central and take full advantage of:}

- Convenient online submission

- Thorough peer review

- No space constraints or color figure charges

- Immediate publication on acceptance

- Inclusion in PubMed, CAS, Scopus and Google Scholar

- Research which is freely available for redistribution 